\title{
GROWTH AND DEVELOPMENT - CATCHING UP
}

\author{
HARE, Paul
}

Economists think they know a great deal about economic growth, both about why countries differ so much in their growth experience, and what needs to be done to get a country on track for faster growth, raising living standards. However, while there are many important theories about growth, and numerous country case studies of outstanding and sustained performance, there are also still too many countries that grow slowly if at all, where economic performance has somehow become 'stuck' at a low level. In the development context, a major policy concern is often to create enough jobs in a given period to employ all or most of those entering the labour force, preferably productively. Thus growth is not just about expanding aggregate output (GDP) but also about large-scale job creation. In the transition economy context, there was not only the complex matter of switching to a market-type economy in quite a short time, but generating growth and employment to catch up with more prosperous neighbours to the West. This has proved harder than many expected.

Kolodko himself has written much about many aspects of economic growth, and has also contributed in important ways to concrete policy formation in Poland (especially when he served as Minister of Finance). In this paper I shall explore the ideas and challenges indicated above, drawing on Kolodko's work as appropriate, but also developing some new ideas that seem to be needed to understand better both growth successes and growth failures around the world.

JEL classification indices: $\mathrm{O} 10, \mathrm{O} 43, \mathrm{P} 40$

Keywords: economic growth, employment, productivity, transition, catching up, institutions

Hare, Paul, Professor Emeritus of Economics at Heriot-Watt University, Edinburgh, U.K. since 1985 , now officially retired and mainly working as an international consultant, often in the Caribbean, but also recently in Tajikistan, Kuwait and North Korea. Worked on transition economies since 1990, with many research grants, consultancy contracts, and publications. Author of Vodka and Pickled Cabbage (2012); co-editor of, and contributor to Handbook of the Economics and Political Economy of Transition (2013). E-mail: paulhare10@gmail.com; p.g.hare@hw.ac.uk 


\section{INTRODUCTION}

Concerns about economic growth have been at the core of economic thought since the time of Adam Smith, whose major work was first published in 1776. While the Wealth of Nations drew heavily on the very early decades of the British industrial revolution for its source material, when general living standards still had not risen very much above pre-industrial levels, it also sought to generalise and even to advance what was, in effect, a new model of the economy. This model saw the economy as a set of interacting and competitive markets, guided by the 'invisible hand', and with limited state intervention to constrain such distortions as monopolies, price fixing and the like, protecting contracts and private property. The government's role was to provide some basic infrastructure which private agents could not do themselves, and to support the 'rule of law'. Hence a small but effective state would be sufficient.

From understanding the growth process in one country to designing policies to stimulate it elsewhere is an enormous leap. It did not prove easy to foster sustained growth and development around the world, though many countries have performed remarkably well. This raises the natural question, how well do we actually understand why and how the apparently 'successful' countries have done so well. And a related question, how well do we understand why some countries, once doing well, slipped back rather badly, and why others are still advancing little, if at all. These are complex questions, and in this short paper we shall do no more than scratch the surface, though I hope also offering some useful insights.

In reflecting on economic growth it makes sense to consider why we care about it as much as we do. On the positive side, we expect growth to raise general living standards (i.e., hopefully not merely for 'the few'), to reduce poverty, to facilitate catch-up with neighbours already more prosperous than ourselves ${ }^{1}$. Usually this progress is measured using the indicator of GDP or real per capita GDP, though this only captures part of what we mean by improving living standards. In one way or another, sustained growth can only occur via improvements in average productivity, involving diverse channels as we shall see. On the negative side, economic growth can be accompanied by environmental damage, including pollution of the sort that is generating global warming, harm to important wildlife (both plants and animals), and much else; this is partly why the UN's Sustainable Development Goals (SDGs) highlight such concerns.

1 The practical difficulties of catching up, or real convergence as it is often termed, are wellknown. Diverse experience of convergence is interestingly analysed in Balcerowicz - Fischer (2006). 
From an individual perspective, one way of becoming considerably better off is through migration from a poor source country to a much more prosperous receiving country. We may only understand quite imperfectly the factors that make one country richer than another - such factors as education levels, the volume and quality of capital stock per worker, institutional factors concerning the business environment, legal conditions and taxation, and the like - but individuals contemplating migration can perceive very well the resulting differences in living standards. And if conditions in their home country are sufficiently dire, then this knowledge will stimulate migration. An interesting question then arises, namely how much migration of people from very different cultural and institutional backgrounds can a prosperous country accept before the migration itself starts to put at risk the very conditions that made for economic success in the first place.

To illustrate the range of recent growth experience around the world, the next section presents a series of examples of individual countries, or country groupings, with brief remarks on what appear to be key factors relevant for explaining their performance, good or bad. Section 3 then reviews some ideas about job creation and growth, both in already fairly developed countries, and in the developing world. Section 4 discusses growth models and policy design, while Section 5 concludes.

\section{EXAMPLES AND CHALLENGES}

About a decade ago the World Bank Growth Commission produced a very interesting report on economic growth, and the factors that appeared to be conducive to sustained economic growth (CGD 2008). The report started by reviewing the experience of 13 economies that had enjoyed at least 25 years of real GDP growth faster than $7 \%$ per annum since 1950, identifying five common features of these countries. These were (CGD 2008: 21):

1. They fully exploited the world economy.

2 . They maintained macroeconomic stability.

3. They mustered high rates of saving and investment.

4. They let markets allocate resources.

5. They had committed, credible, and capable governments.

Of course these are quite complicated and demanding conditions, and much space could be devoted to discussing each in turn. Take for instance the third item, to do with investment. It is not too hard to understand that countries with very low rates of civilian investment, say less than $7-8 \%$ of GDP, are likely to grow very slowly if at all, but the converse is not so clear cut. Thus the former Soviet Union and much of Eastern Europe in the 1980s achieved rates of fixed 
capital formation of $20 \%$ of GDP or even more, yet mostly grew slowly if at all. This illustrates the important point that it is not just the volume of investment that matters, but also its quality - hence the process of investment selection is a crucial feature of a successfully growing economy. Indeed an early chapter in Easterly (2002) argued that investment per se was far less important than usually thought, instead placing far more emphasis on innovation, new technology and total factor productivity.

Now, bearing in mind these five features, let us briefly review some examples of growth experience from around the world, including instances where apparently similar countries have shown remarkable divergence in their economic performance over a period of decades. The choice of countries in what follows is necessarily highly selective, both for space reasons, and because I have chosen just enough countries to illustrate my main points.

\section{(a) Within the EU, the contrast between Ireland and Greece}

As many people have observed, joining the EU and hence adhering to the entire acquis communautaire, following the region's fiscal and monetary policy guidelines, and benefiting from the relevant flows of structural funds from the EU budget, do not guarantee steady and sustained growth, assuring catch up to the EU average per capita income level. EU rules leave plenty of scope for domestic policies to influence a country's economic outcomes, and the cases of Ireland and Greece provide an instructive contrast in this regard. Around 1980, both countries had per capita incomes of roughly $70 \%$ of the EU average, and just before the 2007-2009 financial crisis Ireland had advanced to about 125\% of the EU average, while Greece had remained well below EU average income. Thus Ireland had grown much faster than the EU average, whereas Greece had grown at about the same rate as the EU. Both countries were hit hard by the banking crisis, requiring bail-outs by the troika of the IMF, the European Central Bank and the EU - for Ireland this rescue operation ran from 2010-2013, with some drop in GDP followed by a slow recovery; for Greece, there were several stages of rescue, running from 2010-2018, imposing enormous costs on the economy (including a roughly $25 \%$ drop in real GDP) (for a fuller account of Greece, see Åslund 2018).

Much of the difference between Irish and Greek experiences can be attributed to the functioning of their respective governments (point 5 above), and the effectiveness with which they used EU structural funds to finance major new infrastructure (point 3 above), but to an important extent the financial crisis also highlighted important shortcomings in the functioning of the Eurozone, still far from fully resolved. 


\section{(b) Economies in transition, the contrast between Poland and Ukraine}

In the years 1989-1991, most Central and Eastern European countries and the former Soviet Union abandoned communism and the centrally planned economy, embarking on a process of transition towards market-type economies, in many cases accompanied by democratic politics. ${ }^{2}$ Most countries accomplished the main elements of the transition with commendable alacrity, including the redirection and restructuring of much trade, though leaving a good deal of vital institution building to be implemented more gradually. Naturally, different countries opted for different pathways to the market economy, and many mistakes and mis-judgements occurred along the way, e.g. over managing privatisation. Interestingly, almost no one could have predicted (or, indeed, did predict) exactly which sectors of the economy would prove most successful as these countries transformed.

All these countries experienced post-socialist recessions, Poland's being the shortest and shallowest, Ukraine's one of the longest and deepest. By 1992, Poland's GDP was already rising again, and it continued to do so, despite which unemployment remained stubbornly high, only alleviated somewhat once Poland joined the EU (in 2004) by the UK's immediate openness to migrants (other EU member states maintained controls on free movement until 2013) from the new Eastern countries, including Poland. Poland's transition experience remains one of the most impressive in the region, and the country's income level did catch up significantly with the EU average, though many observers still find the rate and extent of this catch up quite disappointing.

Poland's transition path has been dramatically superior to that of Ukraine. In 1989, both countries had about the same per capita income of just over USD 5000 (in PPP terms, 1989 US dollars), whereas by 2015 Poland's per capita income (again in PPP terms, 2005 US dollars) was about three times that of Ukraine (Hartwell 2016). This is an enormous divergence to have occurred in just 25 years. So what went so badly wrong in Ukraine? In part the country has been seriously unlucky in its politics, with leaders not really understanding what a market economy required, resisting reforms, and engaging in corruption on a massive scale (point 5 above, to some extent also failures of points 1, 2 and 4) ${ }^{3}$.

2 The debate about transition and how best to manage the process was long, complex and at times quite heated, but for reasonably balanced, thoughtful overviews, see Kołodko (2002); Kołodko - Tomkiewicz (2011); Hare (2012); Hare - Turley (2013).

3 In the early 1990s I interviewed senior officials and politicians in Ukraine and was told, 'Ukraine is a special country, the normal economic laws don't apply', and by a central banker I was informed that for two-three years after the break-up of the Soviet Union, the central bank continued to send monthly monetary reports to Moscow and did not really believe that independence would last long. 
Hence the important reforms and institutional development that occurred rapidly and in a well-managed way in Poland scarcely got off the ground in Ukraine.

Economic failure then feeds on itself, leaving the eastern parts of the country, traditionally based on heavy industry and predominantly Russian, highly vulnerable to Russian influence. Hence the annexation of Crimea in 2014 and the attempted breakaway/local autonomy of key eastern regions, Donetsk and Luhansk. Both politically and economically the country has been torn between a Russian orientation and an orientation towards the EU, with the latter resulting in a DCFTA ${ }^{4}$ with Ukraine that came into provisional effect in January 2016. Had Ukraine managed its economy more competently and with far less corruption, I very much doubt whether we would have been witnessing the extent of political instability and division that has arisen.

\section{(c) Strong performance of China since the late 1970s}

An impressively high proportion of the poverty reduction that has occurred around the world in recent decades has taken place in China. ${ }^{5}$

Once the Cultural Revolution came to an end in the mid-1970s, schools and universities quickly re-opened and resumed their normal business, while the economy rapidly took off, stimulated first by the shift from large communes to family or small-group run farms in the countryside, initially with quite short leases, soon on a longer-term basis. While a share of output still had to be delivered to the state, above-quota output could be marketed freely. Output and rural incomes rose rapidly, giving rise to a boom in rural house building (new houses, improvements and extensions to existing ones). Quite soon so called township and village enterprises (TVEs) sprang up, at first in limited areas, experimentally, but the model was quickly adopted across the country. From an institutional perspective, TVEs are a puzzle in that they flourished in an environment with no legally assured property rights, often no more than an informal understanding between local entrepreneurs and local governments - which took a share of the profits when new businesses were successful. Post-Cultural Revolution, there was a tacit understanding that developing new firms was welcome, and they would not be subject to political interference. TVEs employed rural workers displaced from

4 DCFTA means 'Deep and Comprehensive Free Trade Agreement'. It runs to over 2300 printed pages and is seriously complex and ambitious. However, I suspect its impact on Ukraine remains quite limited, despite the EU's good intentions. It is still the case that important institutional conditions needed to make the DCFTA a success for Ukraine are not really yet in place.

5 In the present volume, Roland (2019) is entirely devoted to explaining the Chinese miracle. 
farming, as well as many others living in towns and villages who were underemployed.

By 1980 China was already investing over 30\% of its GDP and achieved GDP growth rates in excess of $10 \%$ per annum. ${ }^{6}$ This spectacular growth was maintained for three decades, initially in the east of the country but gradually spreading to inland regions. The rapid transformation of the country, with modernisation and rising living standards, exceeds anything ever achieved anywhere else in the world. Moreover, this success has come about by following all five of the key features noted above. However, not surprisingly it has been accompanied by severe pollution and environmental damage, which the Chinese government has only belatedly started to address.

In the last few years China's real GDP growth has slowed down to 6 or 7\% per annum, still rapid by international standards. Questions are often asked about the sustainability of the Chinese 'growth model', especially as it has been accompanied by an enormous accumulation of internal debt. This will take some careful management, but so far the Chinese leadership has proved able to cope with its macroeconomic challenges.

\section{(d) Improving performance of other Asian countries such as India and Vietnam}

Soon after the end of World War II, several Asian countries started to grow rapidly, largely assisted by openness to the world economy (point 1), high rates of productive investment (point 3), and competent government (point 5). Such countries included Japan, South Korea, Taiwan, Hong Kong and Singapore, later followed - though less impressively - by Malaysia and Indonesia. These countries were not immune to occasional financial crisis, but they have sustained fast growth and achieved medium to high living standards remarkably quickly. Other important Asian countries like India and Vietnam were slower to open their economies to liberal trade and increasingly free markets, but now seem well set on the path to steady growth and improving living standards. Both countries started out with a socialist orientation, but both have accepted the limitations of state control and regulation, leading to an opening up of their economies; in Vietnam's

6 I visited China twice in the early stages of this rapid development. In 1980 I travelled across the east of the country, and the whole place seemed like a gigantic building site, construction going on everywhere. Since fast growth continued for a long time, one has to infer that the bulk of this investment was productive. In 1984 I was in Shanghai for two months teaching advanced economics to students whose education had been badly disrupted by the Cultural Revolution. At that time Shanghai was being criticised by the Beijing leadership for growing too slowly, a shortcoming that was quickly remedied in the subsequent decades. 
case, this started as in China with major liberalisation in agriculture. Politically, India has been democratic since Independence in 1947, while Vietnam remains a communist country. However, as regards their economic policy and approach to development, both countries have been flexible and pragmatic.

\section{(e) Slow economic growth in the Caribbean}

In contrast to most of Asia, growth in the Caribbean has been slow; in fact according to the IMF, since around 1990 the Caribbean has been the world's slowest growing region (Thacker et al. 2012; IMF 2013; Greenidge et al. 2016). Many factors have been advanced to explain this, though it is not always easy to distinguish causes and effects. For instance the high indebtedness of several Caribbean countries might inhibit growth, but in most cases it was deliberate policies that brought about the indebtedness, not some unforeseen 'accident' or crisis. The Caribbean region comprises many small jurisdictions and the resulting small market size and inability to benefit from economies of scale - both in production and in governance arrangements - might also contribute to slower growth than elsewhere; however, even this is not a wholly convincing story, since the Caribbean has tended to grow even more slowly than other small island developing states (SIDS).

Moreover, the Caribbean possesses a great deal of institutional machinery designed to facilitate cooperation and collective action. At the top level stands Caricom, with its secretariat and statistical service both based in Georgetown, Guyana, supporting the Caribbean Single Market and Economy (CSME) programme (administered from Barbados), and a wide range of regional institutions. For the Eastern Caribbean, there is a currency union (for 8 island economies) overseen by the Eastern Caribbean Central Bank (ECCB) based in St Kitts and Nevis; and a larger Organisation of Eastern Caribbean States (OECS) with a secretariat based in St Lucia. Unfortunately, much of this is under-resourced and probably over-ambitious, and to be more effective it would require a sharper focus, as recent reviews of governance across the Caribbean have urged.

Interestingly, rates of capital formation across the Caribbean were reportedly quite high, according to Roache (2006), forcing one to conclude that on average the investment being undertaken was not very productive, hence explaining the low growth rates. However, in 2010 the ECCB revised downwards the estimated rates of investment across the currency union, leaving the low growth a little less puzzling. What we are left with is a mix of factors to do with lack of scale, investment probably still less productive than it could be, problems of adjusting to the 
end of sugar production and most banana production in the region, perhaps an over-dependence on volatile tourism.

At the same time, comparisons with other parts of the world also suggest that the Caribbean might have missed important economic opportunities. Thus around 1960 both Jamaica and Singapore had very similar levels of per capita income. But the latter was quick to open its economy, while also ensuring very high educational standards for its population, and it became both an entrepot for growing Asian economies, and later a highly research-intensive centre: per capita income levels now are a multiple of Jamaica's. Since much intra-Caribbean trade is now conducted via Miami, this sort of entrepot-type opportunity may no longer be a realistic option for Jamaica, and across the Caribbean the mix of slow growth and uneven educational standards has the unfortunate result that of those young people who do achieve high levels of education, a high proportion finds limited opportunities in the Caribbean and therefore moves elsewhere, often to the US or the UK. This brain drain is a high cost for the Caribbean region.

\section{(f) Disastrously bad economic performance in North Korea, Zimbabwe, Venezuela}

For different reasons, North Korea, Zimbabwe and Venezuela have been performing exceptionally badly, in the latter two cases following periods of much better performance.

\section{North Korea}

After the end of the Korean War in $1953^{7}$, the North Korean economy did grow under its system of central planning, and developed close trading links with the then Soviet Union, and to a lesser degree with China. In 1991 the Soviet Union came to an end, splitting into 15 successor states, with the Russian Federation easily the largest. The new states, notably Russia, quickly decided that their close trade links with North Korea were not in their economic interests, and within a short time most of this trade came to an abrupt end. The ensuing economic shock was a serious blow to North Korea, resulting in empty and abandoned factories because there was no longer a ready market for their mostly fairly poor quality and low technology products. But in a way even more shocking was the failure of North Korea to adjust by developing new products, seeking new markets, and opening the economy both to trade and to foreign investment.

An armistice was signed then, there has never been a formal end to the Korean War, no Peace Treaty. 
Instead, the regime gave priority to its military/defence programmes, including efforts to develop ballistic missiles and nuclear weapons. This has attracted critical UN Security Council resolutions and international sanctions, but there is no sign that these have yet led to any change of course. It is too early to judge whether the most recent discussions between the US, South Korea and North Korea might result in real change. What is completely clear is that the North Korean government's focus on defence programmes and the military has consumed vast resources that could otherwise have been spent on economic development and raising living standards.

The late 1990s were a period of severe famine in North Korea, with many hundreds of thousands of estimated fatalities (Haggard - Noland 2007). Growth has since resumed, albeit at a modest pace, with increased toleration by the government of many market-type side-line activities to support people's livelihoods (Smith 2015). Such quasi-market business is estimated by now to account for at least a third of GDP, though it is hard to be sure as North Korea has published no reliable economic statistics for some decades. Average incomes, especially in the countryside, remain among the lowest in the world, not so surprising given that defence spending is estimated to account for about $25 \%$ of GDP, with civilian investment probably under $5 \%$ of GDP ${ }^{8}$. The blend of extreme militarisation and growing market-type elements make North Korea unique in the world (Lankov 2013).

\section{Zimbabwe}

At independence in 1980, Zimbabwe had a mixed economy with a highly productive and mostly white-owned agriculture, a large manufacturing sector, a growing tourism sector based on a mix of attractive scenery (e.g. Victoria Falls) and abundant wildlife, and promising potential for further growth and development. But there were also unresolved conflicts over land ownership and redistribution, and managing these in due course gave rise to economic disaster for the country. In the 1980s and 1990s land reform proceeded quite slowly, and was based on the payment of compensation (in part paid by the UK government) to white farmers giving up their farms. From 2000 onwards, war veterans and others were simply authorised to dispossess white farmers without any compensation. This speeded

8 As part of a very interesting UNDP project, I had an opportunity to travel to two rural areas of North Korea in late 2015. I have never travelled anywhere in the world with so little sign of investment (aside from a little construction in Pyongyang), so little mechanisation, so few vehicles, and food crops occupying almost every square metre of available space, reflecting continuing food insecurity. 
up the process of land redistribution, but most of the people resettled on these lands knew next to nothing about farming, lacked seed, equipment and technical advice, and the inevitable result was that production, especially of export crops like tobacco, coffee and tea, plummeted; and from being a maize exporter, the country struggled to feed itself. Export earnings collapsed (African Development Bank 2007; WB 2017; Sibanda - Makwata 2017).

During the decade of the 2000s, fiscal discipline became increasingly lax. On the one hand, the fall in production and incomes reduced tax revenues; on the other, there were pressures to raise spending in areas resettled by African farmers, providing better roads, health clinics, schools and other basic infrastructure (much of which was promised but never actually delivered); and additional military spending to finance Zimbabwe's intervention in the Congo. The government resorted to printing money on an increasingly large scale, and inflation took off, reaching record levels by 2006-2008. With domestic currency virtually worthless, it was not surprising that the economy effectively dollarized. This ended the inflation and permitted some economic stabilisation, the resumption of modest economic growth. During these difficult times, a few million Zimbabwe citizens have fled to South Africa to seek work to feed their families, and many others work in the informal sector to obtain their livelihood.

It is arguable that the highly unequal land distribution in Zimbabwe was a problem that had to be tackled, but it has been badly mismanaged resulting in large output and income falls, with very poor macroeconomic management, and a lack of investment. The people of Zimbabwe have been paying a very high price; in particular, the poor who were supposed to be helped by the land reforms have seen no improvement in their meagre living standards. As of late 2018 there is little sign that, under the country's first post-Mugabe government, economic policy and living conditions are improving. Zimbabwe needs much aid and foreign direct investment, but the new government has not gained the confidence of the international community.

\section{Venezuela}

Unfortunately, a somewhat parallel story also applies to Venezuela. Given its large oil reserves and production capacity, the country ought to be one of the more prosperous in Latin America (and for a time, it was), but like other countries in the region the income distribution has been very uneven, with a large fraction of the population remaining very poor and hardly benefiting from economic growth. Popular concerns over this inequality probably helped to bring to power the left-wing leader Hugo Chavez in early 1999. Initially he was lucky, in that 
high oil prices at that time enabled him to spend on various social programmes. ${ }^{9}$ But falling oil prices, poor management of oil revenues, strikes in the oil sector and elsewhere, and investors deterred by the government's readiness to take assets into public ownership soon transformed the outlook. External agencies assessed Venezuelan property rights as among the worst in the world, while the World Bank also rated the country as almost the worst place to do business.

Chavez died in 2013, but his designated successor, Maduro, attempted to continue the same populist policies. Since 2013 the economy has been in freefall, real GDP estimated to have fallen by more than one-third, the lack of foreign currency and falling domestic production leading to severe shortages of many basic items - medicines and other items needed for the health service; basic foodstuffs like bread; items such as toilet paper; and even core services like electricity and potable water. The persistent macroeconomic mismanagement is giving rise to rapidly worsening inflation which, according to the $\mathrm{IMF}^{10}$, could reach $1,000,000 \%$ in 2018 , heralding a probable complete collapse of the currency. In such circumstances, it is not surprising that many people have sought to migrate to neighbouring countries to find some way of making a living.

\section{GROWTH AND JOBS}

Now, after reviewing a range of growth experience, some good, some pretty bad, it is useful to stand back and think more generally about why countries want to see their economies growing.

Countries evidently seek to raise living standards, though this is naturally a more urgent concern for those countries where average incomes are still low, or perhaps at low-middle income levels. Even thinking about living standards, though, it is important always to ask, 'whose living standards'? In other words we should not neglect the question of income distribution. Thus even in the most developed countries, such as the United States, the benefits of growth can be, and in recent decades have been, notably unevenly distributed: since the early 1970s, while the US has enjoyed respectable rates of aggregate GDP growth (around 2\% per annum in real terms), almost none of the gains have accrued to the poorest $40-50 \%$ of the population, most have gone to the best off $5-10 \%$. The economic

9 Weisbrot and Sandoval (2007) reflect these early, optimistic times.

10 The IMF has great difficulties engaging properly with Venezuela, as the country has not permitted the usual Article IV Consultation since 2004. A currency reform in August 2018, rescaling the currency by removing five zeroes, seems not to be stemming inflation or restoring confidence in the currency. 
mechanisms that give rise to such sustained inequality are much debated, as are the political factors that reinforce them - resulting in tax measures that favour those already better off, and choices over the social safety net that exclude many poorer people. In many countries far poorer than the US, a mix of political and economic factors has also often prevented the poorest groups from benefiting much from aggregate economic growth: too much income is taken (sometimes stolen) by the already rich and powerful, stimulating populist revolts and the like. This observation probably helps to explain the recent focus of many aid agencies, including the World Bank and the British aid agency, the Department for International Development (DFID), on promoting what they termed pro-poor growth. Rather than waiting for growth to 'trickle down', eventually benefitting the poorest groups, this approach promoted a range of initiatives intended to benefit the poor directly and quickly. To make this work effectively, and sustainably, proved harder than it sounds.

While incomes matter a great deal, they are not the whole story. In principle we should be concerned with social welfare understood quite broadly, not simply with incomes and consumption. An important aspect of welfare is the amount of leisure available to people in a given society. For those with formal sector jobs (i.e. jobs that are properly registered, subject to contract, with clear terms and conditions, etc.), it is quite common for people to be concerned about the incomeleisure trade off they may face. Some workers might prefer more leisure and a bit less income; others the reverse. Although many workers might still find their choices constrained, on average societies seem to adjust to reflect the predominant pattern of preferences. This is probably why in much of Europe the average worker works fewer hours and enjoys more leisure than his or her US counterpart. This apparent European preference for more leisure was criticised as a reason for Europe's lower incomes in the otherwise excellent and thoughtful book, Åslund and Djankov (2017). Of course the point is right, but it is not especially relevant if we have in mind a wider notion of welfare.

In the labour market, many people face constraints far more severe than the trade-offs just mentioned. These take two main forms:

(i) People may be unemployed. In other words they are in the labour force and actively seeking a formal sector job, but are unable to find one. In better off societies, such people will often receive social benefits, so they should not normally be destitute. However, their income while unemployed will typically be low, and their priority will normally be to find a job of some sort, with the hours of work usually being a lower priority. Ideally, such a job should match their qualifications and experience, and should be available at or near their home location. But such natural desiderata cannot always 
be assured. People often move to find a job, and often end up accepting work at a lower grade than they would prefer.

(ii) In most societies someone who has neither a formal sector job, nor has work in the rural sector (as a farmer or farm labourer), has to find or create a livelihood in order to survive. Especially in poorer societies, there is typically little or no social security provision for those of working age (and often not even much for those of pensionable age), and families are often unable to provide much or any support once their children grow up. Indeed it is not uncommon for children to be required to work to help support their families from quite a young age, hence limiting their access to proper schooling. ${ }^{11}$ Lack of a formal sector job, or an informal sector livelihood might stimulate some people to engage in crime, petty or more serious, as a survival strategy; or if domestic conditions are sufficiently dire, it might force them to migrate to seek better conditions elsewhere. Sometimes training programmes can help people to raise themselves above the bottom rungs of labour market engagement, but in most countries there is poor provision of training, and even when it exists it often targets trades and professions not in great demand. Manpower planning of this sort is incredibly difficult to get right.

These remarks raise important questions about what we should mean by terms like 'jobs' and 'livelihoods', and how we should be measuring the associated statistics. The standard ILO definition of unemployment uses labour force surveys to estimate how many people, and what share of the workforce (usually defined as those of working age, though the exact definition varies somewhat from country to country) are seeking work. Work here usually means formal sector work, and surveys often focus mostly on urban areas, so large sections of the workforce are omitted altogether or measured incompletely. The informal workforce is rarely measured with precision anywhere, if it is measured at all. Where being unemployed brings social benefits (unemployment pay), there is an incentive for those eligible for such payments to register as unemployed. This gives another measure of unemployment, generally lower than that obtained from labour force surveys since not all the unemployed will be eligible, and there are other factors that may deter some people from registering as unemployed. Complicating factors in all this can include religion, ethnicity, health (e.g. disability), and sex

11 In the comfortable West we are often shocked at reports of child labour and the conditions in which children often work. But for their families, it frequently provides vital support for basic living standards. It will only be ended as families grow richer, and hence no longer need child labour to support them. 
(many countries still discriminate against women in important parts of the labour force). Jobs may also be created in the 'wrong' places, requiring people to move to find work.

However, while unemployment is commonly measured with reference to formal sector jobs, and is measured extremely imperfectly, it might be more useful to think about the labour force in broader terms, especially when thinking about growth and how it might best be stimulated in a given country. Thus we can estimate the numbers working in agriculture (including informal, non-farm activities), those in industry (mostly formal sector), and those in services (some formal sector, e.g. banks, hotels, etc.; many in the informal sector), along with their respective contributions to GDP. Combining this with some basic demographic information, it is then possible to judge how many people are likely to leave the workforce in a given period (retirement, net migration, deaths), and how many younger people (those leaving school or higher education, some women returning to work after childbirth, etc.) are likely to join it. The difference between these two numbers gives a first estimate of the annual numbers of new jobs (of all kinds) that the economy needs to create. Moreover, if a relatively low productivity sector, often agriculture in poorer societies, experiences substantial productivity growth through investment in improved techniques of production, the need for labour in that sector will surely fall, adding to the number of net new jobs that the economy must provide. In that sense, productivity growth can seem a mixed blessing, as it both raises GDP - presumably a benefit - but in doing so it displaces more people from the work/jobs they were doing onto the wider labour market. This is more likely to be viewed as a loss to those affected, unless enough new jobs are being created elsewhere.

To give an example of the orders of magnitude involved here, Indian planners recently reported that the economy needs over 10 million new jobs per annum, but is only creating in the formal sector about half that number (even though GDP is currently growing quite well at around $6-7 \%$ per annum). Hence the rest will essentially take the form of informal sector livelihoods, whereby people can just about make a living and hopefully support their families. And this is the situation even without large or rapid improvements in rural productivity, which could displace many millions more people (while raising the incomes of those who remain in agriculture). Similarly in Vietnam, the government there aims to create around 1 million net new jobs each year, but only a small fraction of these are in government or in state-owned enterprises. Most are in the fast growing private sector, with many still in the informal sector providing livelihoods at a fairly basic level.

In much of sub-Saharan Africa, at least until very recently, there has been insufficient private investment to employ all the new workers coming onto the 
labour force. In part this reflects the rapid population growth of the region, and the resulting very young age profile. In turn this places huge demands on each country's education system, with many young people still coming onto the labour market with little or no education. Countries lack the budgets, and the trained teachers, to deliver even basic schooling to everyone, and among young people (aged 15-24) the literacy rate - though rising gradually - only stood at about $70 \%$ in 2011 . This average, of course, masks enormous differences between countries, with a few such as Botswana, Namibia, Mauritius and others achieving near-universal literacy; in some very poor countries, literacy rates are barely above $30 \%$.

The combination of poor skills (albeit slowly improving) and often unstable and/or seriously corrupt politics has discouraged much investment except in extraction (mining, oil, etc.), to some extent in commercial agriculture, and in construction (some new infrastructure, most recently financed and implemented by China). In most of Africa, manufacturing has not so far served as a driver of growth, and indeed its share in GDP has declined in most countries. According to the World Bank Doing Business surveys, much of sub-Saharan Africa has a poor business climate. Taken together, these points depict a rather bleak outlook for economic growth, particularly given the scale of job creation needed in the region. Despite all these drawbacks, African growth has been surprisingly dynamic for the past decade or two, often 5-6\% per annum or even faster. However, as noted above the rate of job creation has not been fast enough to absorb the new workers coming into the labour force each year. In most countries investment rates have remained low and much capital investment has tended to be in capital intensive sectors, hence generating incomes for the few, but creating few new jobs. It is most urgent to see rapid improvements in the business environment, including in the availability of credit, to stimulate the creation of many millions of new private-sector firms.

In this difficult situation where many young people face very poor job prospects, the incentives to ensure a good level of education are quite weak. In addition, while low-income and low-skill livelihoods can ensure basic survival for many, one can well understand why so many young people contemplate migration, usually for economic reasons rather than due to political repression. Such migration can take place in stages: from rural areas or small towns to larger towns and cities; to a neighbouring country if the prospects there seem more promising; much further afield, including north to Europe, if the local conditions are really bad. These processes are both accelerated and magnified by civil wars and political instability (as in Congo and South Sudan), by economic mis-management (as in Zimbabwe), by terrorism (as in northern Nigeria and to some extent in Niger and Mali), and to some extent by climate change (e.g. in the Sahel) and dis- 
ease (e.g. countries vulnerable to malaria, Ebola, or other tropical disease vectors where local health services are functioning badly and lack funding).

The challenge, then, is to design a growth model for Africa (using this region as an important exemplar) that not only raises incomes, but also ensures enough jobs to employ the bulk of the young people joining the labour force. How we might do this is explored in the next section. Clearly it is important both for the African economies themselves, and indirectly for Europe too. For the huge pressures to migrate North will only subside when economic conditions in the main source countries become more positive, presumably with a mix of faster aggregate income growth and much more job creation. For nowadays, information about conditions and opportunities elsewhere is far more extensive than would have been the case even a decade or two ago, and transport costs are also far less than they used to be. Only very stringent and well organised immigration controls in the more developed countries can provide a deterrent to the mass movement of people and even then the unpleasant business of people smuggling finds ways through the controls. Far better, in the longer term, to improve economic conditions in the main sending countries, which needs a mix of political stability, economic growth and job creation on a very large scale.

\section{GROWTH MODELS AND ECONOMIC POLICY}

No one can possibly know which sectors, in which countries will prove the most significant for rapid and sustainable economic growth in Africa. Consequently, traditional ways of thinking about development in terms of economic plans and the like cannot take us very far; nor can reliance on employing people in the public sector, whether this means the various levels of government (public administration and public services, national and lower-level government) or publicly-owned enterprises. For funding government requires budgetary revenues from taxation (including, in some countries, royalties from resource extraction), and state firms (e.g. in water supply, electricity generation, railways, ports, etc.) should ideally operate profitably, which will limit how many workers they can productively employ. ${ }^{12}$ Thus the government can only employ more people if the wider economy is doing well enough to yield growing tax revenues; this was also an important lesson taken on quite early in Eastern Europe, in the process of transition to market-type economies.

12 In many developing countries (and developed countries, for that matter), state firms have often operated very inefficiently, requiring large subsidies to keep them going. Most countries now appreciate that this is rarely a good way to run any sort of business. 
Above all, therefore, job creation and sustainable growth require large numbers of new, private-sector firms. Africa already has many of these, but most are tiny, individual or family owned, unable to benefit from any economies of scale, lacking capital and unable to operate in any other than the most local of markets. Such firms provide basic, survival-type livelihoods for many people, but they cannot drive the economy towards the higher income levels that are so urgently needed. In these circumstances, it is quite tempting to come up with a list of reforms and policy measures to improve the situation in a given country, and in the longer term this is not necessarily a terrible idea. But realistically, most governments, even moderately competent ones that are not too corrupt, can only cope with a bare handful of reform issues at a time.

Hence it is perhaps better to follow the more focused approach of Rodrik (2003, 2007) in trying to identify the specific factors that are constraining growth and investment, and then give priority to reforms that help to lift these key constraints. The relevant factors and constraints can differ greatly between countries, so this approach requires careful analysis to produce tailored advice for each country.

In any event, for much of sub-Saharan Africa (and quite a few other places around the world), part of any such 'reform package' is almost certain to include measures to improve the business environment in the very concrete and practical ways highlighted by the World Bank's annual Doing Business surveys. ${ }^{13}$ Since in most countries, most small firms fail within five years, making start-ups quick, easy and cheap is especially important, as is ensuring that business closures are well managed. Lots of start-up firms are needed to give rise to the successes of the future (and we have no idea what these will prove to be), while the assets and expertise accumulated by failing firms need to be passed on to others. In this sense economic development - if not disturbed too much by political disorder and corruption - is a large-scale learning process.

A very simple and quite crude model, with three sectors, can be used to illustrate this process, and to show the scale of the challenge to achieve rapid growth with near full employment. The three sectors are a modern sector that requires investment to expand ${ }^{14}$, and which employs workers at a high productivity level; the output of this sector is denoted $\mathrm{M}$. Then there is agriculture which employs many people at a low productivity level, producing the food needed for the whole population; the output of this sector is A. The third sector is the informal sector that

13 For instance, reducing the costs and the number of procedures and permits associated with setting up a properly registered business; improving electricity and water supplies to new firms, making these services far more reliable; and much else besides.

14 In line with earlier remarks, it is not unreasonable to treat the term 'investment' here as including innovation and new technology. 
employs everyone else, enabling them to produce enough to provide a basic livelihood; output of this sector is N. A few equations give the basic model. Thus:

GDP

Employment

$$
\mathrm{Y}=\mathrm{M}+\mathrm{A}+\mathrm{N}
$$

where $p$ is the rate of growth of

productivity in agriculture

(initially assumed to be zero).

Investment (to expand $\mathrm{M}$ )

$$
\mathrm{I}=\mathrm{sY}
$$

Output of $\mathrm{M}$ (for domestic supplies $\mathrm{M}=\mathrm{mK}, \dot{\mathrm{K}}=\mathrm{I}$

and could also be exported)

Agricultural output (fixed food $\quad \mathrm{A}=\mathrm{aE}$

output per worker, no trade in food)

Employment (no unemployment, $\quad \mathrm{E}=\mathrm{E}_{0} \mathrm{e}^{\mathrm{nt}}$ constant growth rate, $\mathrm{n}$ )

Output of $\mathrm{N}$ (residual) $\quad \mathrm{N}=\left(\mathrm{E}-\mathrm{e}_{1} \mathrm{M}-\mathrm{e}_{2} \cdot \mathrm{e}^{\mathrm{pt}} \mathrm{A}\right) / \mathrm{e}_{3}$

In these equations, lower-case letters are fixed parameters that can be varied as needed to generate alternative growth paths for the economy being modelled. $\mathrm{E}_{0}$, the initial size of the labour force/employment, is also given; and to solve the model we also need an initial value for the capital stock in the modern sector, $\mathrm{K}_{0}$. While solving the model algebraically is quite messy, and not very illuminating, it is straightforward to insert suitable parameter and initial values, then run the model as a simulation exercise to explore the behaviour of this imagined economy. This is most easily done using an Excel spreadsheet.

Table 1 shows the initial values chosen to set the model running. It is assumed that sectors $\mathrm{A}$ and $\mathrm{N}$ both require one unit of labour to obtain one unit of output,

Table 1. Initial values and parameters

\begin{tabular}{l|l|l|l|l|l|l|l}
\hline Initial GDP, Y & 100 & $\begin{array}{l}\text { Initial modern } \\
\text { sector output, } \mathrm{M}\end{array}$ & 20 & $\begin{array}{l}\text { Initial agri- } \\
\text { cultural sector } \\
\text { output, } \mathrm{A}\end{array}$ & 30 & $\begin{array}{l}\text { Initial informal } \\
\text { output, } \mathrm{N}\end{array}$ & 50 \\
\hline Employment, $\mathrm{E}_{0}$ & 84 & $\mathrm{e}_{1}$ & 0.2 & $\mathrm{e}_{2}$ & 1 & $\mathrm{e}_{3}$ & \\
\hline $\begin{array}{l}\text { Employment } \\
\text { growth rate, } \mathrm{n}\end{array}$ & 0.02 & $\begin{array}{l}\text { Food per worker, } \\
\mathrm{a}\end{array}$ & $\begin{array}{l}30 / 84 \\
=0.36\end{array}$ & Initial K & 60 & $\begin{array}{l}\text { Output - capi- } \\
\text { tal ratio, } \mathrm{m}\end{array}$ & 0.33 \\
\hline Savings ratio, $\mathrm{s}$ & 0.1 & $\begin{array}{l}\text { Rate of growth } \\
\text { of productivity in } \\
\text { agriculture, } \mathrm{p}\end{array}$ & 0.0 & & & & \\
\hline
\end{tabular}


while the modern sector is five times as productive. The output-capital ratio in the modern sector is assumed to be one-third ( 0.33$)$ and the economy-wide aggregate savings ratio (s) is assumed to be $10 \%$ (i.e., 0.1 ). There is no government in this model, so no variables to represent taxes and government spending; likewise, while some modern sector output might be exported, trade and the external sector are not explicitly modelled here.

In this simple framework it is quite easy to plot several possible growth paths for our model economy. For the sake of brevity, we restrict attention here to just three such paths, namely:

(a) Base case, all assumptions as in Table 1;

(b) Higher investment in modern sector, $\mathrm{s}=0.15$;

(c) Higher investment in modern sector $(s=0.15)$ plus rising labour productivity in the agriculture sector; productivity, $\mathrm{p}$, rising at $2.5 \%$ per year.

For each of these three variants of the three-sector model, output and employment shares over a 40-year period are shown in the charts below. For the Base Case solutions, it can be seen (Chart 1) that agriculture's share of GDP slowly declines, though its share of employment is unchanged because there is no improvement in agricultural productivity, and the size of the sector adjusts over time to provide just sufficient food for the entire population. With food imports or exports, this picture of the agriculture sector could clearly look very different. The output and employment shares of the modern sector steadily rise, while those of

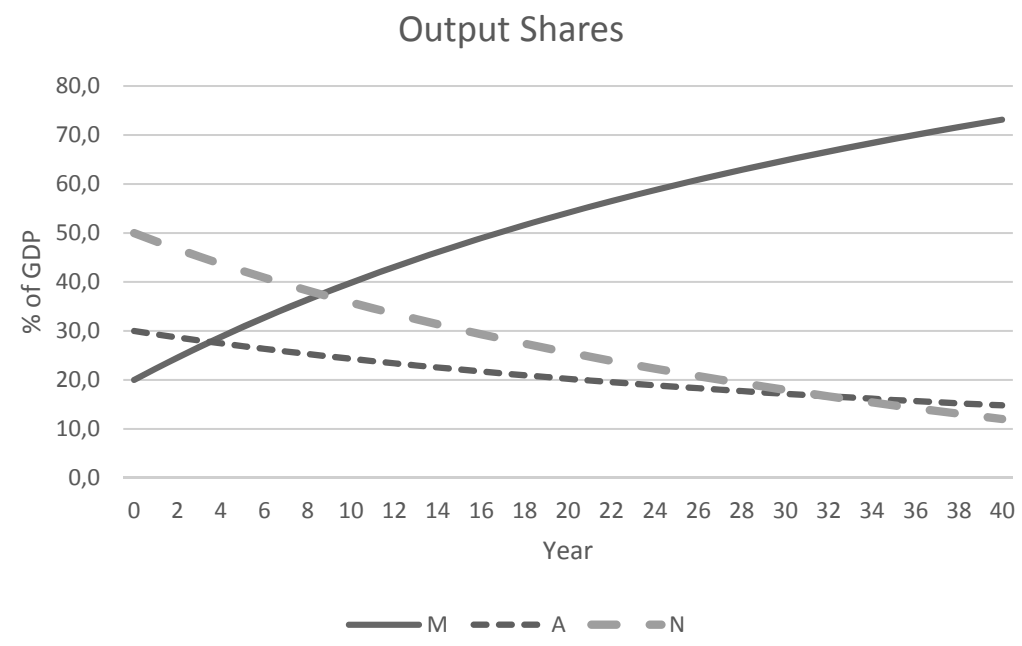

Chart 1A. Base case, output shares 
Employment Shares

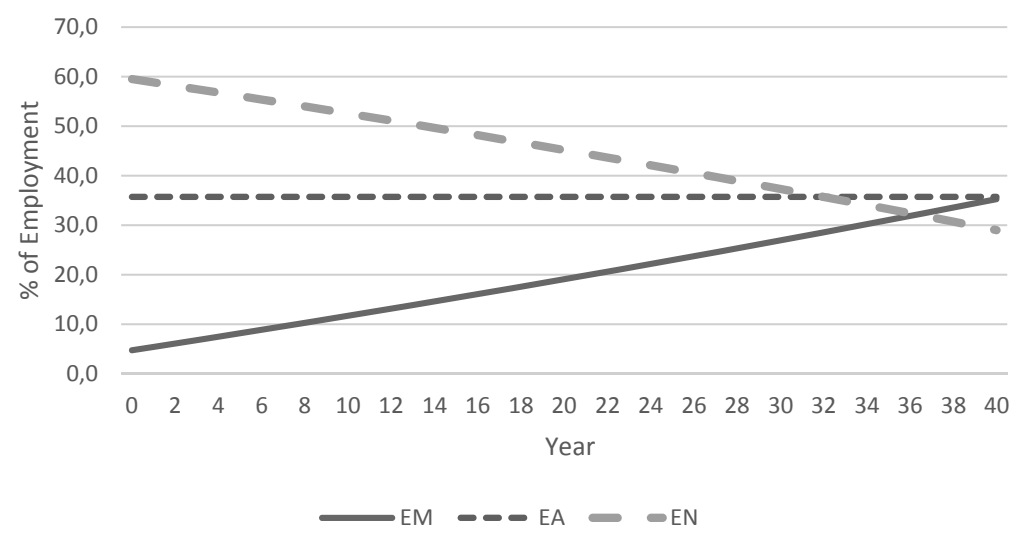

Chart 1B. Base case, employment shares

the informal sector fall. Gradually, this economy is creating more 'proper' jobs, but it is quite a slow process.

In the second scenario, with higher investment in the modern sector, it can be seen from Chart 2 that both output and employment shares in modern sector production rise more rapidly than in the first (base case) scenario, with modern sector output accounting for almost all production by the end of our 40-year period. Correspondingly, the share of GDP accounted for by agriculture slowly falls, while the share of the informal sector drops virtually to zero. Hence in this

\section{Output Shares}

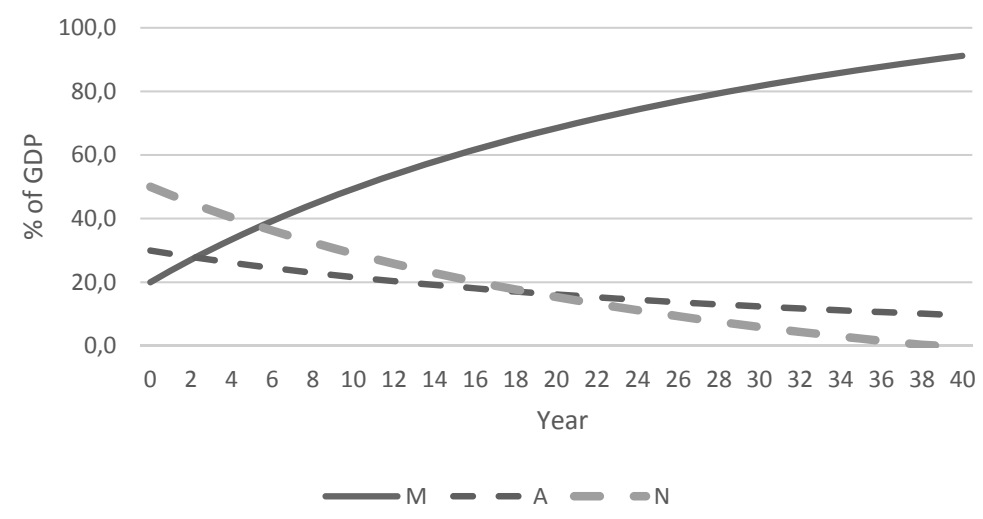

Chart 2A. More investment in modern sector, output shares 


\section{Employment Shares}

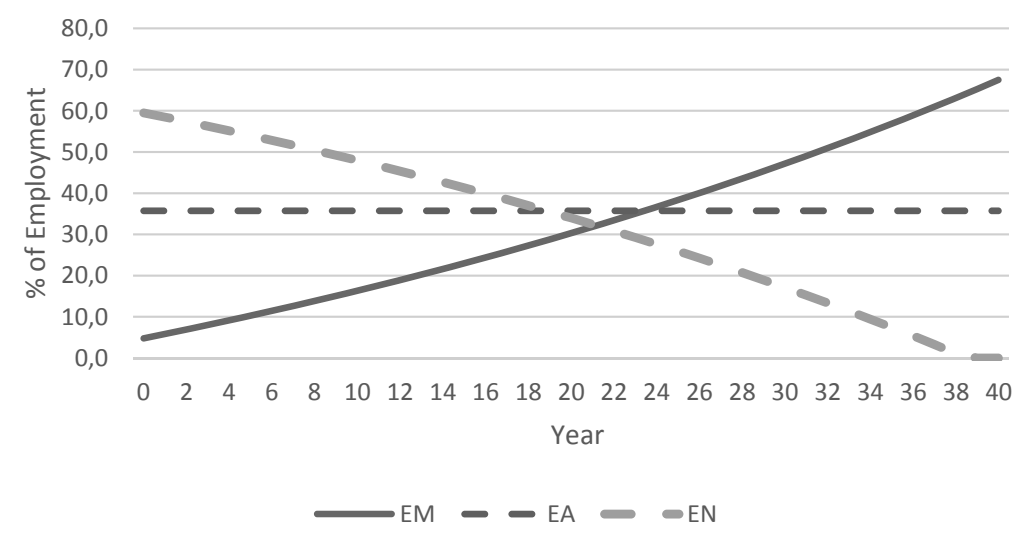

Chart 2B. More investment in modern sector, employment shares

solution, although agriculture remains an unproductive sector, enough modern sector jobs are created to provide jobs to everyone occupied outside agriculture. If agriculture itself gradually becomes more productive, as in our third scenario, the situation changes again, but in an interesting way.

Chart 3 shows the evolution of output and employment shares in our third scenario, with agricultural productivity steadily improving. Not only does the share of GDP accounted for by agricultural production fall, but so does the employment share. The improvements in agriculture, however, displace more workers from the sector, since in our model we only need enough agricultural output to feed the domestic population - as noted above, this simple model makes no provision either for food imports or for agricultural exports. The resulting exodus of workers from farming, even though the modern sector is investing a lot and growing rapidly, implies that more people will have to make a livelihood for themselves in the informal sector, and for longer. Even after 40 years, the informal sector still employs over $10 \%$ of the workforce. In this sense, improving agriculture is a double-edged sword: on the one hand it contributes to overall growth and productivity in the economy as a whole; but on the other hand, it slows down the relative and absolute decline of the informal sector, as modern sector jobs are still not being created fast enough to employ everyone. This illustrates one of the difficult and challenging dilemmas of development policy.

So what do we learn from this model? For brevity, we merely list a few observations:

(a) A model with three sectors is helpful since substantial structural change occurs as the economy grows; a single sector model could not show this; 


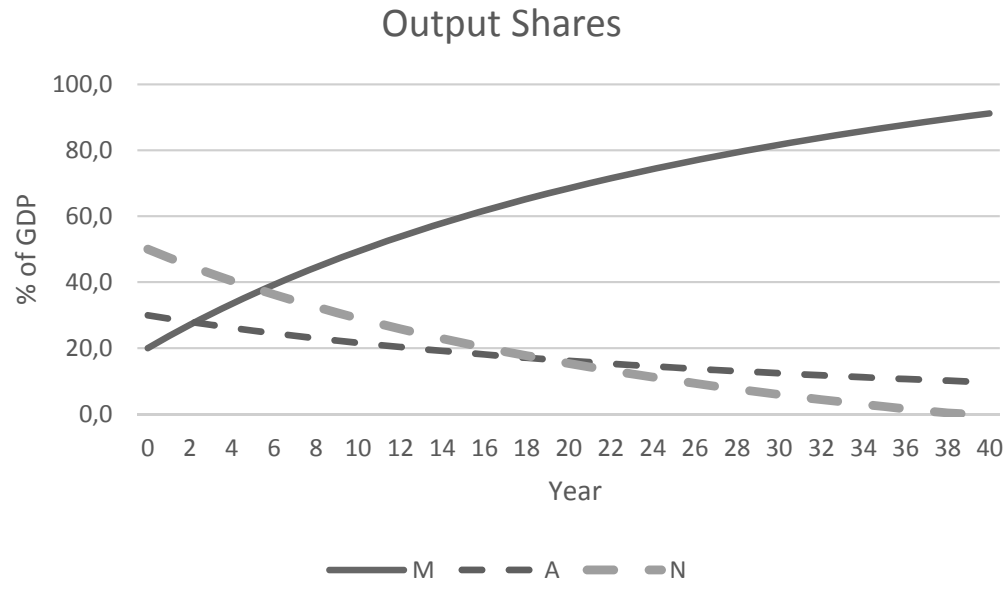

Employment Shares

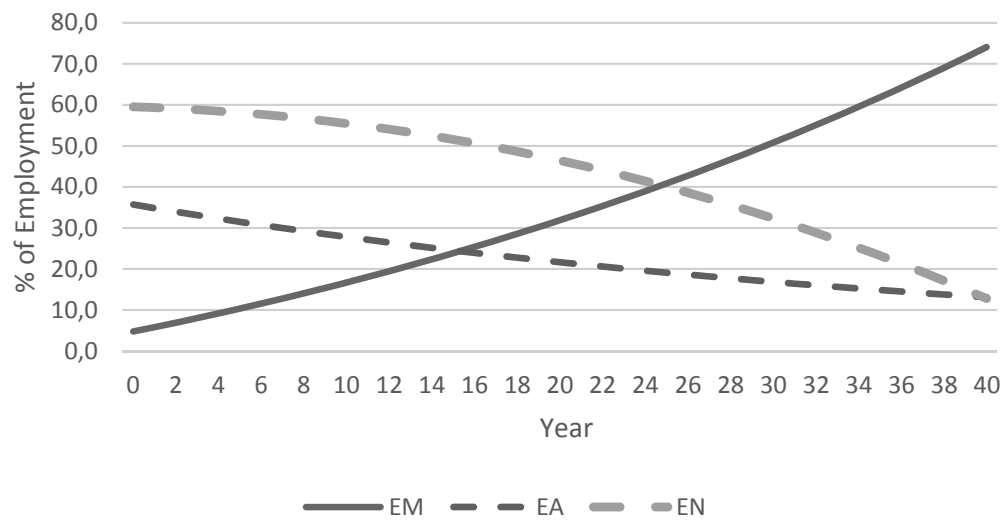

Chart 3. Improving agricultural productivity, output and employment shares

(b) It is useful to track both output trends and employment trends;

(c) In order to appreciate how an economy can be transformed, it is important to study it over quite long time periods;

(d) Problems such as a large informal sector cannot be resolved quickly as that would require an unrealistically rapid rate of modern-sector job creation;

(e) Improving production conditions in one sector (such as agriculture in our third scenario above) can feed back onto the informal sector, raising the numbers of people who have to create a livelihood there, and leaving them there for longer. 
(f) Growth in this model comes about through a mix of investment in the modern sector, improving production conditions in agriculture, and shifting people between sectors. Another channel, not modelled here, would be improving skills and raising incomes in the informal sector.

\section{CONCLUSIONS}

Economic growth is a difficult business. From the World Bank's Growth Commission report it was possible to identify a set of five conditions that appear to be necessary conditions for successful, sustained economic growth, and we listed these in Section 2, above. However, reasonable and comprehensive as these conditions may appear, they are far from being sufficient conditions for growth. Further, each of the conditions is open to a variety of interpretations and implementations, implying that we lack an 'on the shelf' standard model for economic growth that ought to work anywhere. Real economies are a lot more complicated than such a line of thinking might imply.

On the other hand, while we cannot pin down exactly the conditions needed for successful growth, it is a little easier, as some of the examples in Section 2 suggested, to identify conditions conducive to economic failure. These include exceptionally poor macroeconomic management, with the public finances running large deficits, spending funded by printing money, and in the end episodes of hyperinflation. These conditions characterised Zimbabwe not long ago, though the country has pulled back a little from the worst excesses; and Venezuela is currently following very much the same route. In both these cases, there is substantial evidence that corruption at various levels has helped to make a bad situation much worse. Especially in the early 1990s, Ukraine came close to adopting this disastrous model.

North Korea's story is a bit different, in that its macroeconomic management has not been so terrible. But its insistence on centralised state control over the economy, only fairly recently giving way to greater toleration of markets and quasi-private activity; and its failure to adjust and restructure following the loss of Soviet markets in the early 1990s have cost the economy a great deal in terms of incomes and living standards. Low rates of productive investment and high defence spending have not helped.

Now, following the abandonment of communist rule, the transition economies in Central and Eastern Europe had two aims: an economic one, to transform themselves into market-type economies with a view to catching up with the living standards of more developed western countries; and a political one, to join the western system of alliances, including the EU. For quite a while, it was widely thought that 
joining the EU - adopting the entire acquis communautaire, including those parts concerning democracy and the rule of law - would itself be sufficient to ensure catching up and economic convergence. However, it is by now well understood that this is not so. EU membership still leaves enough scope for domestic policymaking that it cannot guarantee rapid growth, and there is room for debate over which parts of the acquis are really important for growth, which parts rather reflect the EU's social democratic political model. For instance it is doubtful whether an economic adviser to any of the new member states of the EU would recommend adopting the entire acquis if the adviser's aim was simply to promote economic growth. Especially for smaller or less developed new member states, several chapters of the acquis communautaire are too complicated and arguably premature in terms of what the countries really needed. However, as applicants to join the EU, they naturally had no option but to adopt and implement the entire package.

As we saw in Section 3, and illustrated with a three-sector model in Section 4, a core developmental issue in much of the developing world concerns jobs. In the absence of social welfare provision, anyone lacking either a 'proper' job in the modern sector, or employment in agriculture, has somehow to create a livelihood for themselves in the informal sector. How they do this is usually unclear or poorly understood. Development involves both modern sector growth and job creation, with a good deal of the output being exported, and usually some modernisation of agriculture. The size and evolution of the informal sector then depends on the relative pace of these two processes, as our model illustrated. Absorbing a large informal sector takes time, even when the modern sector is growing quite rapidly, so it can be helpful to enhance training to boost informal sector skills (and hence, one hopes, incomes) and also to make the business environment as user friendly as possible. In this way, those in the informal sector can be assisted and encouraged to set up more and better new businesses, perhaps creating firms capable of expansion and job creation in their own right. In the best cases, some of these firms will be able to engage in more distant markets, including by importing and exporting.

To sum up, for successful economic growth we certainly need active engagement with the world economy, an adequate standard of macroeconomic management, and decent rates of well chosen, productive investment. In addition, tolerably competent and not overly corrupt government is always helpful, along with a range of institutional conditions to do with property rights, the legal framework and the business environment. This last is very hard to pin down with much precision, and as we have seen it is much easier to identify cases where these conditions are failing badly, than to specify exactly what conditions must be in place to ensure good growth. Hence we still have much to learn. However, it is also worth emphasising here the important role that can be played by sheer good fortune in determining the economic outcomes for a given country. 


\section{REFERENCES}

African Development Bank (2007): Zimbabwe: Country Dialogue Paper 2007. Tunis.

Åslund, A. (2018): Lessons from the Greek Tragedy. Acta Oeconomica, 68(S2): 71-84.

Åslund, A. - Djankov, S. (2017): Europe's Growth Challenge. Oxford: Oxford University Press.

Balcerowicz, L. - Fischer, S. (2006): Living Standards and the Wealth of Nations: Successes and Failures in Real Convergence. Cambridge, Mass.: MIT Press.

CGD (2008): The Growth Report: Strategies for Sustained Growth and Inclusive Development. Commission on Growth and Development, Washington, D.C.: World Bank.

Easterly, W. (2002): The Elusive Quest for Growth: Economists'Adventures and Misadventures in the Tropics. Cambridge, Mass.: MIT Press.

Greenidge, K. - McIntyre, M. A. - Yun, H. (2016): Structural Reform and Growth: What Really Matters? Evidence from the Caribbean. IMF Working Paper, No. 82.

Haggard, S. - Noland, M. (2007): Famine in North Korea: Markets, Aid and Reform. New York: Columbia University Press.

Hare, P. (2012): Vodka and Pickled Cabbage: Eastern European Travels of a Professional Economist. CreateSpace Independent Publishing Platform (originally published in 2010).

Hare, P. - Turley, G. (eds) (2013): Handbook of the Economics and Political Economy of Transition. London: Routledge.

Hartwell, C. A. (2016): Two Roads Diverge: The Transition Experience of Poland and Ukraine. Cambridge: Cambridge University Press.

IMF (2013): Caribbean Small States: Challenges of High Debt and Low Growth. Washington, D.C.

Kolodko, G. (2002): Globalization and Catching-up In Transition Economies. Rochester, N.Y.: University of Rochester Press.

Kolodko, G. - Tomkiewicz, J. (2011): 20 Years of Transformation: Achievements, Problems and Perspectives. New York: Nova Science Publishers.

Lankov, A. (2013): The Real North Korea: Life and Politics in the Failed Stalinist Utopia. New York: Oxford University Press.

Roache, S. K. (2006): Domestic Investment and the Cost of Capital in the Caribbean. IMF Working Paper, No. 152.

Rodrik, D. (editor and contributor) (2003): In Search of Prosperity: Analytic Narratives on Economic Growth. Princeton, NJ: Princeton University Press.

Rodrik, D. (2007): One Economics, Many Recipes: Globalization, Institutions and Economic Growth. Princeton, NJ: Princeton University Press.

Sibanda, V. - Makwata, R. (2017): Zimbabwe Post Independence Economic Policies: A Critical Review. Saarbrücken, Germany: LAP Lambert Academic Publishers.

Smith, A. (1776): An Inquiry into the Nature and Causes of the Wealth of Nations. London.

Smith, H. (2015): North Korea: Markets and Military Rule. Cambridge: Cambridge University Press.

Thacker, N. - Acevedo, S. - Perrelli, R. (2012): Caribbean Growth in an International Perspective: The Role of Tourism and Size. IMF Working Paper, No. 235.

WB (2017): Zimbabwe Economic Update: The State in the Economy. Washington, D.C.: The World Bank.

Weisbrot, M. - Sandoval, L. (2007): The Venezuelan Economy in the Chavez Years. New York: Center for Economic and Policy Research. 